Research Article

\title{
Occupational Change and Socioeconomic Status among Dalit Communities in Kaski District
}

\author{
Netra Prasad Subedi \\ Lecturer, Janapriya Multiple Campus, Faculty of Management, Pokhara, Nepal \\ Corresponding email: netrapsdsubedi@gmail.com
}

\begin{tabular}{c} 
Article History \\
Received 14 April $2021 \quad$ Revised 10 September $2021 \quad$ Accepted 21 November 2021 \\
\hline
\end{tabular}

\begin{abstract}
The purpose of the study is to examine the occupational change, socio-economic status among, and the inherent association between occupational changes and socioeconomic status. This study has conducted among the people of Nepali, Pariyar, and Bishwokarma caste of the Dalit communities in the Kaski district of Nepal using the quantitative nature of the information collected from primary sources with the help of a structured questionnaire. The total sample of this study is 300 head of the family member covering 150 from each urban and rural geographical region consisting of 50 from each caste. The data and results show the involvement in a particular occupation in the past and at present have significant variation, as well as the tendency of leaving the caste-based traditional occupation and adopting new \& modern occupations is high. From the overall economic perspective, Nepali caste people stand at the first position followed by Bishowkarma, and the last position occupied by Pariyar. While looking from the socio-cultural perspective, Bishowkarma caste people stand at the first position followed by Nepali, and the last position occupied by Pariyar. At the regional level, residence of urban areas have a better overall economic and socio-cultural position compared to the rural areas. However, test statistics reveal the economic status is statistically significant at the caste and regional level whereas, the socio-cultural status is not statistically significant at both caste and regional levels. Finally, while investigating the association between occupational change and socioeconomic status, the results reveal that the overall economic status is the best of those people who have completely changed their past occupations while the overall socio-cultural position is the best of those who have not changed. However, these variations are not statistically significant.
\end{abstract}

(C) The Author, published by JRCC, Janapriya Multiple Campus. 
Keywords: Bishowkarma, caste, communities, status, Dalit, Nepali, occupational change, Pariyar, socioeconomic

\section{INTRODUCTION}

The association between socioeconomic status (SES) and health has been widely documented. However, the role of occupation in this association is not clear because occupation is less often used than income and education as an indicator of SES, especially in the United States. This may be caused by the ambiguity in what occupation represents: both healthenhancing resources (e.g., self-affirmation) and health damaging hazards (e.g., job stress). SES has two aspects: resources and status. While income and education represent resources and imply status, occupational prestige is an explicit indicator of the social status afforded by one's occupation. The findings not only suggest multiple ways that occupation is associated with health, but also highlight the utility of occupational prestige as an SES indicator that explicitly represents social standing (Fajishiro, Xu \& Gong, 2010).

Although the socio-economic effects of occupational changes as well as unemployment have received substantial scientific attention, the interrelation of both is not as clear. While occupational changes cannot be considered negative in all cases, especially in conjunction with unemployment experiences they could possibly have severe negative effects on an individual's socio-economic situation after re-employment. In cases of prior unemployment an occupational change is far more likely to be involuntary than when changing directly from one job to the other, possibly leading to a more pronounced negative impact on the socioeconomic situation (Bethmann, 2013).

Nepal is a multiethnic, multi-religious, multicultural and multilingual society. Despite this diversity, as the only Hindu kingdom in the world, the Hindu religion and the all-pervasive caste system have a hegemonic hold on the Nepali society. The caste system has its roots in the ancient religious texts of the Hindu religion as well as the codes and traditions derived from them. It is social stratification of all Hindus into four main classes, known as Varna (castes): Brahman (priest), Kshatriya (warrior), Vaisya (farmer or merchant) and Shudra (menial worker). The castes are exclusively based on occupations and are hereditary. Thus, a Hindu is born into a caste and, except under special circumstances, cannot escape from it. In the caste hierarchy, the groups of people commonly known today as Dalits occupy the lowest rung (International Labor Organization [ILO], 2005).

The term, 'Dalit', is generally used to identify those on the lowest rung in the caste 
hierarchy. In most writings, the term is also used to identify the vulnerable and poor groups of people who are oppressed, suppressed and exploited. The nomenclature, 'Dalit', was chosen by Dalit activists in India, rejecting other more widely accepted terms, for example untouchable, scheduled castes, depressed classes or Gandhi term, 'harijan' (meaning God's people). These developments in India influenced Nepalese activists. This term, as well as the concept associated with it, has received wide acceptance in Nepal in recent years. Nepalese Dalits, thus, increasingly reject the terms, 'achhut' (untouchable), 'sano jaat' (low caste), 'paani nachalne jaat' (water unacceptable castes), etc, and instead find their true identity in the term, Dalit (ILO, 2005).

According to the census of 2011 four geographical regions of Nepal, viz mountains, hills, inner terai, and terai, Dalits are found in almost all hill districts, whereas mountain districts have sparser Dalit populations. The Dalit population is higher in the hill and mountain regions combined (72.84\%) than in the terai and inner terai combined (27.16\%). The hills and mountains of Dalit including Kami, Damai, and Sarki occupy 7.95 percent of the total population of Nepal (CBS, 2012). In the hills and mountains Sarki writes Nepali, Kami writes Bishowkarma and Damai writes Pariyar as a surname for their identity.

Traditionally each caste group had specific occupations. However, some occupations also have been found adopted by more than a single caste. In hilly and mountain areas the most common traditional occupations of the Bishowkarma are blacksmith, coppersmith, goldsmith work, and wooden-pot making. Tailoring, playing a musical instrument (Panche Baja), dancing, entertaining, and singing are the traditional occupations of Pariyar caste group and cobbler, leather related works, and wooden related works are the traditional occupations of Nepali caste group (ILO, 2005).

Dalits have been relegated to do caste-based work as black/goldsmiths, tailors, shoemakers and street cleaners, all are considered of low social status. Poverty and lack of other means of livelihood force the Dalits to continue their traditional occupations. Dalit women and children are also forced to work in the households of their landlords. They do not get a justifiable wage for their labor. If they do not work for others, they work as helpers of their husbands in the traditional jobs of Dalits. Those working in Haliya Pratha (bonded labor) or Khala Pratha (forced labor) are not even earning from their work. They may get food grains. Lack of modern technology skills and financial resources prevent them from getting employed in new industries or trade in the market. Dalits who change from traditional occupation to wage labor do not therefore necessarily improve their economic condition (Shrestha, 2002). 
In recent times there is a rapid occupational shift in Dalit communities. The major causes for the occupational mobility issues among the Kami include socio-cultural practices, modernization, industrialization, urbanization, and widespread use of the western education system (Chetry, 2010).

Traditional Skill Technology (TST) of the Dalits was found on the verge of extinction barring some skills. In the majority of households, there is not a single member who knows about TST, which shows a decline of TST among the Dalits in the study area. But there is a remarkable intergroup variation. The Knowledge of TST is very poor among the Nepali group but it is far better among the Pariyars. It also shows that transfer of traditional occupational skills is very limited among the Nepali and high among the Pariyars. Two major TSTs of Dalits, such as ironwork and leatherwork, which are traditionally tied to Bishowkarma and Nepali groups respectively, are rapidly disappearing. The factory-produced commodities have been replacing the handmade traditional goods with a high price. Sewing or tailoring is the widely known TST of Pariyars. Pariyars are the only group that has maintained the knowledge of the traditional occupation. This is also because the sewing skill is still in demand in the market. The study clearly indicates that younger generations from Dalit groups are no longer interested in learning these TSTs. It can be said that knowledge about Dalit TSTs is gradually disappearing (Parajuli, 2012).

Although the major traditional occupations such as metalwork, tailoring, leatherwork, and sweeping, cleaning, and waste disposal are still associated particularly with Dalit caste groups, 42 percent of the respondents were still engaged in such occupations on a parttime basis only. This means that Dalit groups are gradually diversifying into non-traditional avenues, mainly to agricultural wage labor. Such occupational mobility among castes such as Damai, Kami, and Sarki/Chamar is largely due to the encroachment of modern factoryproduced goods and the traditional non-cash mode of the transaction (Dalit Ngo Federation [DNF], 2002).

Whatsoever the situation of occupational caste, especially of Dalit caste group, in the past time, the traditional occupations, skills, and technology have significant value in recent time in terms of earnings and cultural identity. But the studies show that the youth of Dalit communities have been abandoning their traditional occupations and losing their skill, technology, and cultural identity. Therefore, investigating current social and economic status, occupational involvement in the past and at present, occupational change structure, and the association between occupational change and socioeconomic status are the major concerns 
of this study. Therefore, the general objective of this paper is to investigate the occupational change and socioeconomic status among Dalit communities of Kaski.

\section{DATA AND METHODS}

This study was conducted in the Kaski district of Nepal. The study has adopted descriptive cum analytical research design. In this study, primary data have been collected through a selfadministered structured questionnaire from rural and urban areas. The questionnaire contains closed-ended, single and multiple-choice, and Likert-type questionnaires. This study has adopted the judgmental and quota sampling technique. The total sample size of the study is 300 households comprising 150 from each urban and rural area. And from each area, 50 household data have been used for each Dalit caste group namely; Nepali, Pariyar, and Bishwokarma. Equal size of sample has been used from each region and caste group to make consistency and comparability in the analysis. The collected data have been processed through SPSS version 26. In order to arrive at a finding of the research objectives, descriptive statistical tools such as percentage, mean, minimum, maximum, standard deviation have been used.

Similarly, inferential statistical tools such as chi-square, independent sample t-test, paired sample t-test, and analysis of variance (ANOVA) have been used as per the requirement of nature of data and analysis. To quantify the economic and social status of the respondents, literally identified and used indicators have been used to measure the socioeconomic status. The identified constructs and variables have been assigned weighting scores and the weighted score mean value is used to measure the socioeconomic status among the Dalit communities. In order to develop appropriate weighting scores scholarly used scales such as Kuppuswamy's socio-economic status scale, modified BG Prasad scale, Udai Pareek revised scale (Singh, Sharma, \& Nagesh, 2017), and the study of Cuc and Griffin have been taken as the reference (Cuc \& Griffin, 2007). As per a general rule of thumb to conduct a pilot test on a survey on 30 to 100 participants (SAGE., 2016), a pilot survey conducted on 30 people of Dalit communities. After conducting the pilot survey necessary amendments were made in the questionnaire and on the methodology to increase the reliability and validity.

\section{RESULTS AND DISCUSSION}

\section{Respondents' Profile}

Altogether 300 head of the families are the sample of this study. Each urban and rural 
areas covers equal percentage (50\%) of respondents. And each area includes 50 respondents from each Nepali, Pariyar, and Bishwokarma caste groups which accounting to 33.33 percent.

\section{Economic Status}

Table 1 presents the descriptive statistics of the overall economic status of respondents based on caste group. The data reveals that the Nepali caste has the strongest economic status with an overall mean score of 3.039 , followed by the Bishowkarma with an overall mean score of 2.921 and the weakest status of Pariyar with the lowest mean score of 2.856 and lowest standard deviation indicates more consistency of mean score compare to Nepali and Bishowkarma castes.

Table 1

Descriptive Statistics for Overall Economic Status Based on Caste ( $=300)$

\begin{tabular}{llllllll}
\hline Caste & Frequency & $\begin{array}{l}\text { Weighted } \\
\text { score }\end{array}$ & Mean & Min & Max & S.D. & Rank \\
\hline Nepali & 100 & 303.910 & 3.04 & 1.91 & 4.18 & 0.480 & 1 \\
Pariyar & 100 & 285.630 & 2.86 & 1.64 & 3.73 & 0.354 & 3 \\
Bishowkarma & 100 & 292.120 & 2.92 & 1.80 & 4.00 & 0.461 & 2 \\
\hline
\end{tabular}

Table 2 presents descriptive statistics for the overall economic status of respondents based on areas. The data shows that people living in the urban areas have a stronger economic status with an overall mean score of 3.023 compared to people living in the rural areas with an overall mean score of 2.855. The value of standard deviation indicates variability in the result of the mean score. Lower the standard deviation for an urban area with 0.413 indicates less variability or more consistency of the result for urban people in comparison to people living in a rural area with a slightly higher standard deviation of 0.456 .

\section{Table 2}

Descriptive Statistics for Overall Economic Status Based on Areas ( $n=300)$

\begin{tabular}{llllllll}
\hline Area & Frequency & Weighted score & Mean & Min & Max & S.D. & Rank \\
\hline Urban & 150 & 453.45 & 3.023 & 1.64 & 4.18 & 0.413 & 1 \\
Rural & 150 & 428.21 & 2.854 & 1.80 & 4.09 & 0.456 & 2 \\
\hline
\end{tabular}

\section{Difference in Economic Status}

A one-way ANOVA test has conducted to examine whether there is a statistically significant difference among the Dalit communities in terms of overall economic status. This indicates that there is a statistically significant difference in Dalit communities in terms of 
overall economic status $(\mathrm{F}=4.495$ with, $p<0.05)$. It revealed that a significant difference exists between Nepali and Pariyar castes but not between Nepali and Bishowkarma, and Bishowkarma and Pariyar. Similarly, independent samples t-test has conducted to test whether there is a statistically significant difference between the mean scores of overall economic status among the Dalit communities in two regional levels (i.e. urban and rural areas). This result showed that there is a statistically significant difference in the mean score of overall economic status in the Dalit communities between urban and rural areas $(t=3.351$ with $\mathrm{p}<0.05)$.

\section{Difference in Socio-cultural Status}

Table 3 presents descriptive statistics for the overall socio-cultural status of respondents based on caste groups. The statistical data indicates that the Bishowkarma caste group has the best socio-cultural status with an overall mean score of 1.870 followed by the Nepali caste group with a mean score of 1.852 and lastly Pariyar with a mean score of 1.828 .

\section{Table 3}

Overall Socio-Cultural Status Based on Caste $(n=300)$

\begin{tabular}{|c|c|c|c|c|c|c|c|}
\hline Caste & Frequency & $\begin{array}{l}\text { Weighted } \\
\text { score }\end{array}$ & Mean & Min & Max & S.D. & Rank \\
\hline Nepali & 100 & 185.17 & 1.852 & 1.00 & 3.00 & 0.457 & 2 \\
\hline Pariyar & 100 & 182.83 & 1.828 & 0.83 & 2.83 & 0.413 & 3 \\
\hline Bishwokarma & 100 & 187.00 & 1.870 & 0.67 & 3.17 & 0.428 & 1 \\
\hline
\end{tabular}

\section{Occupational Involvement in the Past and Present}

Table 4 shows the status of occupational involvement in the past and at present. Here, past occupations refer to those occupations that were adopted by the parents of the respondents, and current occupations refer to those occupations that are presently adopted by the respondents. The study identifies that there was involvement in 17 different types of occupations. The data indicate that there was the largest number of involvement in agriculture occupation accounting to 36 percent in the past followed by tailoring and playing Panche Baja (13.67\%), farming labor (13.67\%), iron metalwork and blacksmith (9\%), foreign employment $(8.33 \%)$, carpenter $(6 \%)$ and size of involvement in other new occupation were insignificance. Presently, the occupational involvement and the volume reveal different results. 
Table 4

Occupational Involvement in the Past and Present

\begin{tabular}{llllll}
\hline Occupation & $\begin{array}{l}\text { Involvement } \\
\text { in Past }\end{array}$ & $\begin{array}{l}\text { Percent } \\
(\%)\end{array}$ & $\begin{array}{l}\text { Involvement } \\
\text { at present }\end{array}$ & $\begin{array}{l}\text { Percent } \\
(\%)\end{array}$ & Change \\
\hline $\begin{array}{l}\text { Tailoring and } \\
\text { panche baja }\end{array}$ & 41 & 13.67 & 44 & 14.67 & 3 \\
Farming labor & 41 & 13.67 & 22 & 7.33 & -19 \\
Industry labor & 0 & 0.00 & 4 & 1.33 & 4 \\
Contractor & 1 & 0.33 & 3 & 1.00 & 2 \\
Agriculture & 108 & 36.00 & 32 & 10.67 & -76 \\
Iron metal_blacksmith & 27 & 9.00 & 9 & 3.00 & -18 \\
Goldsmith & 10 & 3.33 & 5 & 1.67 & -5 \\
Transport related job & 3 & 1.00 & 27 & 9.00 & 24 \\
Teaching & 3 & 1.00 & 8 & 2.67 & 5 \\
Foreign employment & 25 & 8.33 & 48 & 16.00 & 23 \\
Defense force & 8 & 2.67 & 4 & 1.33 & -4 \\
Carpenter & 18 & 6.00 & 21 & 7.00 & 3 \\
Trade and business & 4 & 1.33 & 31 & 10.33 & 27 \\
Tourism related job & 1 & 0.33 & 8 & 2.67 & 7 \\
Private sector job & 1 & 0.33 & 1 & 0.33 & 0 \\
Govt. Sector job & 9 & 3.00 & 28 & 9.33 & 19 \\
Others & 0 & 0.00 & 5 & 1.67 & 5 \\
Total & 300 & 100.00 & 300 & 100.00 & \\
\hline & & & & &
\end{tabular}

Source: Field Survey, 2020

At present, the majority of respondents' involvement is in foreign employment accounting for 16 percent followed by tailoring and Panche Baja (14.67\%), agriculture (10.67\%), trade and business (10.33\%), government job (9.33\%), farming labor (7.33\%), and carpenter (7\%). This data reveals that there is a significant decline in parent occupation to respondent's current occupation especially in agriculture, farming labor, and Iron-metal work, and blacksmith. However, there is a noticeable growth in trade and business, transport-related jobs, foreign employment, and government jobs respectively from past to present. 


\section{Involvement in Traditional and New Occupations}

Table 5 presents the occupational change situation from caste based traditional occupation to new occupations. Since agriculture is a common type of occupation of Nepalese as being an agricultural country, it has been presented separately. The data shows that 45.67 percent were involved in caste-based occupation but this involvement declined to 33.67 percent at present and it is a decline of 26.28 percent from past to present. There was 18.33 percent involvement in new occupations in the past but this has increased to 55.67 percent. It is an increase of 166 percent from past to present. Likewise, there was a 36 percent involvement in agriculture as a farmer which declined to 10.67 percent at present, and a decline of 70.37 percent from past to present. These facts indicate that there is a significant tendency of leaving caste-based traditional occupations and farming and shifting to new types of occupations in the Dalit communities.

\section{Table 5}

Involvement in Traditional and New Occupations

\begin{tabular}{|c|c|c|c|c|c|c|c|}
\hline $\begin{array}{l}\text { Type of } \\
\text { Occupation }\end{array}$ & Occupations & 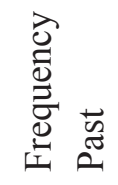 & $\partial^{\circ}$ & 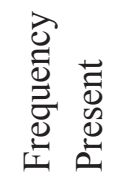 & $a^{\circ}$ & $\begin{array}{l}\infty \\
\text { E } \\
\text { चี }\end{array}$ & 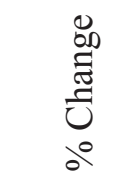 \\
\hline $\begin{array}{l}\text { Caste-based } \\
\text { traditional } \\
\text { occupation }\end{array}$ & $\begin{array}{l}\text { Tailoring, Musician } \\
\text { (Panche Baja), } \\
\text { Ironsmith, Coppersmith, } \\
\text { Goldsmith, Carpenter, } \\
\text { Farming labor }\end{array}$ & 137 & 45.67 & 101 & 33.67 & -36 & -26.28 \\
\hline $\begin{array}{l}\text { Common } \\
\text { occupation }\end{array}$ & Agriculture/ Farmer & 108 & 36.00 & 32 & 10.67 & -76 & -70.37 \\
\hline $\begin{array}{l}\text { New } \\
\text { occupation }\end{array}$ & $\begin{array}{l}\text { Industry Labor, } \\
\text { Transport related Job, } \\
\text { Teaching, Defense } \\
\text { Force, Trade and } \\
\text { business, Tourism } \\
\text { related Job, Private } \\
\text { sector Job, Govt. sector } \\
\text { Job, others } \\
\text { Total }\end{array}$ & 55 & 18.33 & 167 & 55.67 & 112 & 166 \\
\hline
\end{tabular}

Source: Field Survey, 2020 


\section{Occupational Change}

Table 6 presents occupational change in the people of Dalit communities. The nature of change has been categorized into no change (i.e. carrying the same past occupations), partial change (i.e. involvement in past as well as new occupation), and complete change (i.e. completely abended the past occupations). The data reveals there is a 50 percent complete change in the past occupation followed by 27 percent no change, and 23 percent partial change in the Nepali caste group. In the Pariyar caste group, 52 percent completely changed in the past occupation followed by 41 percent no change and only 7 percent changed partially. Likewise in the Bishwokarma caste group, 42 percent did not change the previous occupation, followed by 37 percent completely changed and 21 percent changed partially. In aggregate, the figure of a complete change in the past occupation is the largest accounting for 46.33 percent followed by 36.67 percent no change, and 17 percent partial change in the past occupations.

\section{Table 6}

Occupational Change According to Caste $(n=300)$

\begin{tabular}{llll}
\hline Caste & No change & $\begin{array}{l}\text { Partially } \\
\text { change }\end{array}$ & $\begin{array}{l}\text { Completely } \\
\text { change }\end{array}$ \\
\hline Nepali & 27 & 23 & 50 \\
Pariyar & 41 & 7 & 52 \\
Bishwokarma & 42 & 21 & 37 \\
Total & 110 & 51 & 139 \\
Percent & 36.67 & 17.00 & 46.33 \\
\hline
\end{tabular}

Source: Field Survey, 2020

Pearson Chi-Square statistics (15.641 with $d f=4$, with $p<0.05)$ shows the sufficient evidence to explain that there is a statistically significant association between caste and nature of occupational change situation. Similarly, the Phi and Cramer's $V$ value of 0.228 indicates a very strong association between caste and nature of occupational change situation, and it is significant as well.

\section{Occupational Change and Socio-Economic Status}

Table 8 presents the descriptive statistics of occupational changes and overall economic status. The results depict that the people who have changed their past occupation completely, have the highest overall mean score of 3.001. This result slightly indicates the positive impact on economic status due to complete change in the past occupation followed by the mean value of 2.891 for the people who did not change their past occupation and lastly mean value of 
2.872 for the people who partially change their past occupation.

Table 7

Occupational Change and Overall Economic Status ( $n=300)$

\begin{tabular}{llllllll}
\hline $\begin{array}{l}\text { Occupational } \\
\text { Change }\end{array}$ & Status & N & Percent & Mean & $\begin{array}{l}\text { Std. } \\
\text { Deviation }\end{array}$ & Min & Max \\
\hline No change & Overall Economic & 110 & 36.67 & 2.891 & 0.448 & 1.64 & 4.00 \\
Partial change & Overall Economic & 51 & 17.00 & 2.872 & 0.462 & 2.00 & 4.00 \\
Complete change & Overall Economic & 139 & 46.33 & 3.001 & 0.425 & 1.91 & 4.18 \\
\hline
\end{tabular}

Source: Field Survey, 2020

There is no improvement in the socio-cultural status of those people who have to change their past occupations. The overall mean value of socio-cultural status is in a declining trend from no change to completely change. The mean value is the highest at 1.862 for no change in the past occupations followed by 1.846 for partial change and 1.842 for complete change.

Table 8

Occupational Change and Overall Socio-Cultural Status ( $n=300)$

\begin{tabular}{llllllll}
\hline $\begin{array}{l}\text { Occupational } \\
\text { Change }\end{array}$ & Status & N & Percent & Mean & $\begin{array}{l}\text { Std. } \\
\text { Deviation }\end{array}$ & Min & Max \\
\hline No change & Overall socio-cultural & 110 & 36.67 & 1.862 & 0.435 & 1.00 & 3.17 \\
Partial change & Overall socio-cultural & 51 & 17.00 & 1.846 & 0.424 & 0.83 & 3.00 \\
Complete change & Overall socio-cultural & 139 & 46.33 & 1.842 & 0.436 & 0.67 & 3.00 \\
\hline
\end{tabular}

Source: Field Survey, 2020

\section{CONCLUSION}

It is revealed that overall economic is better among Bishwokarma, and Pariyar are in the low position. People of Dalit communities living in the urban areas have a better overall economic status compare to rural areas. In terms of socio-cultural status, people of the Bishowkarma caste group are in the best position followed by Nepali, and Pariyar caste group are in the last position. Changes have been observed in the involvement in a particular occupation in the past and at present. There is an increasing tendency of leaving traditional \& caste-based occupations and shifting to new \& modern types of occupations in the new generation of Dalit communities in Kaski District at present. The results indicate a better economic status for those people of Dalit communities, who have completely changed the previously adopted occupations, and poor economic status for those people, who have partially changed. Similarly, the socio-cultural 
status is better for those people who did not change their previously adopted occupations and poor for those who have completely changed the previously adopted occupations. This study shows that occupational change has a positive impact on economic status and a little bit negative effect on socio-cultural status.

\section{REFERENCES}

Bethmann, A. (2013). Occupational change and status mobility. The detrimental effects of unemployment and the loss of occupation specific human capital. Journal for Labor Market Research, 307-319. Doi: 10.1007/s12651-013-0147-9

CBS. (2012). National population and housing census 2011. Central Bureau of Statistics.

Chetry, D. B. (2010). Changing occupation pattern among the Bishwokarmas: A case study of Hemja VDC. Himalayan Journal of Sociology and Antropology, 4, 49-60.

Cuc, N. T., \& Griffin, P. (2007). Development of a scale to measure economic status of students in rural Vietnam. Asia Pacific Education Review, 8 (2), 205-215.

DNF. (2002). Caste-based prejudice and discrimination in Nepal. Danida/HUGOU by the Dalit NGO Federation of Nepal. Kathmandu: DNF.

Fajishiro, K., Xu, J., \& Gong, F. (2010). What does “occupation" represent as an indicator of socioeconomic status? Exploring occupational prestige and health. Social Science \& Medicine, 71 (2010), 2100-2107.

ILO. (2005). Dalits and labor in Nepal: Discrimination and forced labor. International Labor Organization.

Parajuli, B. K. (2012). Knowledge and practice of traditional skill technology among hill Dalit of Kaski: A study based on Pariyar, Nepali and Bishowkarma of Kaski District. Himalayan Journal of Sociology \& Anthropology, 5, 19-33.

SAGE (2016). Pretesting and pilot testing. Retrieved from https://www.sagepub.com/sites/ default/files/upm-binaries/68507_Ruel_Chapter_6.pdf

Shrestha, A. (2002). Dalits in Nepal: Story of discrimination. Retrieved from Asian-Pacific Human Rights Information Centre: https://www.hurights.or.jp/archives/focus/ section2/2002/12/dalits-in-nepal-story-of-discrimination.html

Singh, T., Sharma, S., \& Nagesh, S. (2017). Socio-economic status scales updated for 2017. International Journal of Research in Medical Sciences, 5 (7), 3264-3267. 